Рекомендована д. мед. наук, профр. О. М. Олещук

УДК 615.244:547.79]:612.013:615.916

DOI 10.11603/2312-0967.2017.1.7524

\title{
КОРИГУВАЛЬНИЙ ВПЛИВ ТІОТРИАЗОЛІНУ НА ТОКСИЧНІСТЬ І СТАН ПРО- ТА АНТИОКСИДАНТНОГО ГОМЕОСТАЗУ В ЩУРІВ ЗА УМОВ ТОКСИЧНОї ДІї НАНОХРОМУ ЦИТРАТУ
}

\author{
(c) К. В. Садогурська, Р. Б. Косуба, І. М. Яремій
}

\author{
ВДНЗ «Буковинський державний медичний університет», Чернівці \\ sadogurska.katya@mail.ru
}

\begin{abstract}
Мета роботи. Вивчити коригувальний вплив тіотриазоліну на загальну токсичність та параметри біохімічної детоксикації за дії токсичних доз нанохрому цитрату.

Матеріали і методи. У гострому досліді на щурах досліджено вплив тіотриазоліну (100 мг/кг) на токсичність нанохрому цитрату (НХЦ) і стан про- та антиоксидантного гомеостазу на тлі одноразового введення сублетальних $\left(\mathrm{DL}_{0}\right)$ та летальних $\left(\mathrm{DL}_{50}, \mathrm{DL}_{100}\right)$ доз сполуки (3 мг/кг, 4,5 мг/кг, 5 мг/кг). В еритроцитах крові визначали вміст малонового альдегіду (MA), відновленого глутатіону (Г-SH) та активність каталази (КТ). У плазмі крові - загальну антиоксидантну активність (AOA), вміст окисно-модисрікованих білків (ОМБ) та вільних SH-груп. У постядерних супернатантах гомогенатів печінки визначали вміст МА, Г-SH, ОМБ та активність КТ.

Результати й обговорення. Введення тіотриазоліну з лікувальною метою на тлі сублетальних і летальних доз НХЦ значно зменшило загальні прояви отруєння, подовжило життя тварин. Якщо неліковані тварини гинули на 2-3 добу, то при дії тіотриазоліну - на 6-8 добу. При введенні токсичних доз НХЦ посилюються процеси вільнорадикального окиснення ліпідів і променів, знижується активність КТ, АОА плазми крові, вміст вільних SН-груп та відновленого Г-SH. Ефрективнішою виявилася дія тіотріазоліну на тлі мінімально токсичної дози НХЦ (3 мг/кг) - порівняно 3 нелікованими тваринами вірогідно зросла АOA в плазмі крові без помітних змін вмісту SH-груп.

Висновки. У гострому досліді на щурах на тлі токсичних доз нанохрому цитрату тривале введення тіотриазоліну зменшує прояви інтоксикації та летальність тварин. Тіотріазолін запобігає розвитку порушень оксидантноантиоксидантного гомеостазу в організмі інтоксикованих тварин, однак на тлі летальних доз нанохрому цитрату одноразове введення тіотриазоліну малоесрективне.
\end{abstract}

Ключові слова: нанохрому цитрат; токсичність; про- і антиоксидантний гомеостаз; тіотриазолін.

Вступ. Завдяки нанотехнологіям сучасний етап розвитку науки поповнився новими матеріалами 3 унікальними властивостями. Хімічні речовини в нанометровому діапазоні набувають принципово нових властивостей, що розширює можливості їх застосування $[11,12]$. Однак розвиток нанотехнологій та отримання нових наноматеріалів спонукає науковців до необхідності дослідження їх безпеки з метою уникнення можливих несприятливих наслідків як для здоров'я людини, так і навколишнього середовища [12].

В Українському державному науково-дослідницькому інституті нанобіотехнологій і ресурсозбереження шляхом електроімпульсної аквананотехнології отримано органічну сполуку хрому - нанохрому цитрат (НХЦ) [14]. Така сполука хрому, як життєво необхідного мікроелемента [10, 19], викликала інтерес щодо вивчення її біологічної активності та перспектив використання в біології та медицині. Встановлено, що додавання до основного харчового раціону тварин наночастинок хрому покращує апетит, збіль- шує середньодобовий приріст маси тіла [21]. У науковій літературі з'явились експериментальні дослідження щодо позитивного впливу НХЦ на обмінні процеси в організмі сільськогосподарських тварин (свині, кролі) та можливого застосування його як харчову добавку у ветеринарній практиці [4]. Попередніми нашими дослідженнями встановлено, що токсичність НХЦ залежить не тільки від уведеної дози, а й шляхів надходження в організм. Так, при ентеральному застосуванні, згідно з класифрікацією К. К. Сидорова (1973 р.), НХЦ може бути віднесений до «Помірно токсичних сполук», а при внутрішньовенному, внутрішньоочеревинному - це «Високотоксична сполука» [16].

Одним із шляхів підвищення безпечності НХЦ могло б стати призначення речовин-коректорів 3 метаболітотропною дією, зокрема, вітчизняний лікарський засіб тіотриазолін (морфолінієва сіль-3-метил-1,2,4триазоліл-5-тіооцотової кислоти). 3 хімічної точки зору фрармакофрором тіотриазоліну є ядро триазолу, що має нелокалізовану р-електронну хмару з висо-

ISSN 2312-0967. Фармацевтичний часопис. 2017. № 1 
Фармакологічні дослідження біологічно активних речовин Pharmacological researches of biologically active substances

кою реакційною здатністю. Атом сірки в молекулі володіє певною надлишковою електронною густиною через нерівнозначний вплив на нього гетероциклу і карбонільної групи. Завдяки такій хімічній будові тіотриазолін має високу біологічну активність і низьку токсичність $[1,15]$. У медичну практику тіотриазолін увійшов з 90-х років минулого століття як метаболітотропний засіб з вираженою антиоксидантною активністю та політропним спектром терапевтичної дії. Тіотриазолін пригнічує утворення активних фрорм кисню, попереджає окиснювальну модифрікацію білкових структур, може конкурувати з SH-групами білкових молекул за супероксидний аніон-радикал, сприяє нормалізації активності каталази, глутатіонпероксидази, збереженню резервів глутатіону відновленого $[6,8]$. Йому властива гепатопротекторна, кардіопротекторна, нефропротекторна, імуномоделююча та інші властивості $[1,5,6,15]$. Можливість тіотриазоліну одночасно впливати на різні органи і системи, безпечність при застосуванні, зручні фрармацевтичні форми надають йому переваги над іншими відомими метаболітотропними препаратами. Крім того, тіотриазолін проявляє антитоксичну дію при інтоксикаціях деякими важкими металами [13]. Однак наявність у тіотриазоліну протекторної активності щодо негативних ефектів НХЦ ще не вивчалась.

Метою даної роботи стало вивчення коригувального впливу тіотриазоліну на загальну токсичність та параметри біохімічної детоксикації за дії токсичних доз нанохрому цитрату.

Матеріали і методи. Дослідження проведено на статевозрілих лабораторних щурах масою 150-200 г. Тварини були поділені на 2 групи. У першій (42 тварини) - вивчали вплив тіотриазоліну на гостру токсичність НХЦ (ТОВ «Наноматеріали та нанотехнології», 200 мг/л) при введенні його в сублетальних і летальних дозах: 3 мг/кг $\left(D_{0}\right), 4,5$ мг/кг $\left(D_{50}\right)$ та 5 мг/кг $\left(\mathrm{DL}_{100}\right)$ [16]. Через 2 год після одноразового внутрішньоочеревинного (в/о) введення сполуки для корекції токсичності з лікувально-профілактичною метою тваринам в/о вводили тіотриазолін (АТ «Галичфрарм») впродовж 7 діб в дозі 100 мг/кг [15]. Контролем слугували тварини, яким в аналогічному об'ємі, що і дослідним, уводили воду для ін'єкцій. Результати виживаності дослідних тварин порівнювали з отруєними НХЦ (неліковані) та з інтактним контролем. За твари- нами спостерігали впродовж 14 діб після введення НХЦ. Звертали увагу на зовнішній вигляд, поведінку, ритм та частоту дихання, ставлення до їжі, час виникнення та прояви інтоксикації, її перебіг, час загибелі тварин. У наступній групі дослідів (42 тварини) - досліджували показники про- та антиоксидантної рівноваги в організмі щурів на тлі одноразового уведення токсичних доз НХЦ (3 мг/кг, 4,5 мг/кг, 5 мг/кг) та тіотриазоліну (100 мг/кг). На наступний день проводили біохімічні дослідження, біосубстратами для яких слугували кров та печінка тварин. В еритроцитах крові визначали вміст малонового альдегіду (МА) за реакцією з тіобарбітуровою кислотою [17], вміст відновленого глутатіону (Г-SH) титрометричним методом та активність каталази (КТ) [7]. У плазмі крові визначали загальну антиоксидантну активність (АОА), вміст окисно-модифікованих білків (ОМБ) [9] та вільних HS-груп [2]. Гомогенати печінки (5\%) тварин готували на холоді на 50 мМ трис-НCl-буфері $(\mathrm{pH}=7,4)$. У постядерних супернатантах гомогенатів визначали вміст MA, Г-SH, ОМБ та активність КТ [18]. Утримання тварин та всі маніпуляції проводилися відповідно до методичних рекомендацій ДЕЦ МОЗ України 3 доклінічного вивчення лікарських засобів [3] та Європейської конвенції щодо захисту хребетних тварин, які використовуються 3 дослідницькими та іншими цілями (Страсбург, 1986). Статистичну обробку отриманих даних проводили з використанням програм «Excel-7» та параметричних методів статистики 3 визначенням t-критерію Стьюдента. Різницю вважали вірогідною при $\mathrm{p} \leq 0,05$.

Результати й обговорення. У гострому досліді після одноразового введення НХЦ в токсичних дозах у тварин пригнічувалася рухова активність, утруднювалося дихання, періодично виникали тонічні судоми. Падіж тварин відбувався на 2-3 добу на тлі загального пригнічення. Введення тіотриазоліну з лікувальною метою на тлі сублетальних і летальних доз НХЦ значно зменшило загальні прояви отруєння, подовжило життя тварин, летальність наставала пізніше - на 6-8 добу. Після введення НХЦ в дозі 4,5 мг/ кг $\left(\mathrm{DL}_{50}\right)$ загинула половина тварин, а у лікованих тіотриазоліном виживаність зросла в 1,7 раза (табл. 1). На тлі введення абсолютно смертельної дози НХЦ (5 мг/кг) виживаність лікованих тварин склала 83,3 \%. Отримані фракти свідчать про наявність у тіотриазолі-

Таблиця 1. Вплив тіотриазоліну (100 мг/кг) на виживаність щурів на тлі введення токсичних і летальних доз нанохрому цитрату (НХЦ), $\mathrm{n}=6$

\begin{tabular}{|c|c|c|}
\hline \multirow{2}{*}{ Умови досліду } & $\begin{array}{c}\text { НХЦ } \\
\text { (неліковані тварини) }\end{array}$ & $\begin{array}{c}\text { НХЦ + тіотриазолін } \\
\text { (ліковані тварини) }\end{array}$ \\
\cline { 2 - 3 } & вижило / загинуло & вижило / загинуло \\
\hline Контроль & - & $6 / 0$ \\
\hline НХЦ, 3 мг/кг $\left(\mathrm{DL}_{0}\right)$ & $6 / 0$ & $5 / 1$ \\
\hline НХЦ, 4,5 мг/кг $\left(\mathrm{DL}_{50}\right)$ & $3 / 3$ & $5 / 1$ \\
\hline НХЦ, $5 \mathrm{mг/кг}\left(\mathrm{DL}_{100}\right)$ & $0 / 6$ & - \\
\hline
\end{tabular}

Примітка: $\mathrm{n}$ - кількість тварин у кожній серії.

ISSN 2312-0967. Pharmaceutical review. 2017. № 1 
Фармакологічні дослідження біологічно активних речовин Pharmacological researches of biologically active substances

ну антитоксичної дії. У тварин, що вижили, відновлення рухової активності та споживання їжі відбувалося впродовж першої доби.

У наступних серіях дослідів для з'ясування можливих механізмів коригувальної детоксикуючої дії тіотриазоліну досліджено стан про- та антиоксидантної рівноваги на тлі токсичних доз НХЦ (табл. 2, 3). Як виявилося, за дії токсичних доз НХЦ в організмі тварин спостерігається значне порушення оксидантноантиоксидантної рівноваги. У крові та печінці нелікованих тварин зростає вміст продуктів вільнорадикального окислення ліпідів і біополімерів. В еритроцитах крові щурів із збільшенням дози НХЦ (3 мг/кг, 4,5 мг/кг, 5 мг/кг) вміст МА порівняно з контрольними тваринами відповідно зріс на $18 \%, 22 \%, 27 \%$ (табл. 2), а в печінці - на 19 \%, 25 \%, 35 \% (табл. 3). У сироватці крові із збільшенням доз НХЦ вміст ОМБ також пропорційно зріс на $19 \%, 26 \%, 37 \%$, у печінці на 34 - $36 \%$, що свідчить про активацію прооксидантної системи в організмі отруєних тварин.

щодо досліджуваних показників, що характеризують систему антиоксидантного захисту при введенні НХЦ у вищезазначених дозах, то в усіх тварин, які отримували високі дози сполуки, загальна АОА плазми крові знизилася, відповідно, на $27 \%$, $30 \%, 47 \%$, вміст вільних SH-груп знизився на $11 \%$, $14 \%$, $33 \%$ (табл. 2). У крові та печінці щурів знизився також вміст Г-SH як одного з основних ендогенних антиоксидантів (в еритроцитах крові на - 17-45 \%, у печінці на 13-35 \%). При введенні високих доз НХЦ як у крові, так і у печінці щурів знизилась активність КТ - ще одного з ключових фрерментів антиоксидантного захисту (табл. 2, 3). У літературі зустрічаються суперечливі дані щодо впливу сполук хрому на системи антиоксидантного захисту [6]. Катіони хрому (III) можуть виступати в організмі як антиоксиданти, а у великих дозах як і прооксиданти [20], що узгоджується з отриманими нами даними.

Уведення тіотриазоліну на тлі інтоксикації великими дозами НХЦ запобігає прогресуванню порушень оксидантно-антиоксидантної рівноваги в організмі інтоксикованих щурів. Однак ефективнішою виявилася дія тіотриазоліну при введенні НХЦ лише в мінімально токсичній дозі (3 мг/кг). У щурів даної групи вірогідно зросла порівняно з нелікованими тваринами AOA в плазмі крові, вміст SH-груп не відрізнявся від показників інтактних тварин (табл. 2). Оскільки одноразове уведення тіотриазоліну на тлі летальних доз НХЦ виявилося малоефективним, 3 метою коригувальної дії доцільним може бути тривале (курсове) його застосування, про що засвідчили отримані нами результати зменшення токсичної дії сполуки та збільшення виживаності тварин при повторному введенні тіотриазоліну на тлі токсичних доз НХЦ (табл. 1).

Загалом, позитивний корегувальний ефект тіотриазоліну щодо зменшення токсичності НХЦ зумовлений, імовірно, не тільки його здатністю відновлювати порушену за умов інтоксикації оксидантно-антиокси-

Таблиця 2. Вплив нанохрому цитрату на показники оксидантно-антиоксидантного гомеостазу в крові щурів $(\mathrm{M} \pm \mathrm{m} ; \mathrm{n}=6)$

\begin{tabular}{|c|c|c|c|c|c|c|c|}
\hline \multirow{3}{*}{ Показники } & \multicolumn{7}{|c|}{ Умови досліду } \\
\hline & \multirow{2}{*}{ Контроль } & \multicolumn{3}{|c|}{ Нанохрому цитрат } & \multicolumn{3}{|c|}{ Нанохрому цитрат + тіотриазолін } \\
\hline & & $3 \mathrm{Mr} / \mathrm{kr}$ & $4,5 \mathrm{Mr} / \mathrm{Kr}$ & $5 \mathrm{Mr} / \mathrm{K \Gamma}$ & $3 \mathrm{Mr} / \mathrm{Kг}$ & 4,5 мг/кг & $5 \mathrm{Mr} / \mathrm{k \Gamma}$ \\
\hline $\begin{array}{l}\text { Вільні SH-групи, } \\
\text { мкмоль/мл }\end{array}$ & 02 & $0,49 \pm 0,02$ & $0,47 \pm 0,02$ & $0,37 \pm 0,02^{*}$ & $0,54 \pm 0,02$ & $0,40 \pm 0,02^{*}$ & $0,40 \pm 0,02^{*}$ \\
\hline OMБ, & $1,13=$ & $1,40 \pm$ & $1,52 \pm$ & $1,80 \pm 0,05^{\star}$ & $1,32 \pm 0,08$ & 1,42 & $1,44 \pm 0,06 \#$ \\
\hline МА, мкмоль/л & $12,67 \pm 0,49$ & $15,44 \pm 0,17$ & $16,25 \pm 0,23^{*}$ & $17,47 \pm 0,61^{*}$ & $14,03 \pm 0,33$ & $14,70 \pm 0,18^{*}, \#$ & $17,51 \pm 0,18^{*}$ \\
\hline Г-SH, мкмоль/мл & $1,72 \pm 0,04$ & $1,43 \pm 0,04^{*}$ & $1,16 \pm 0,03^{*}$ & $0,95 \pm 0,05^{*}$ & $1,48 \pm 0,02^{*}$ & $1,39 \pm 0,04^{*}$ & $1,09 \pm 0,05^{\star}$ \\
\hline $\mathrm{KT}, \mathrm{MK}$ & $19,8 \pm 0,72$ & $18,01 \pm 0,37$ & $16,15 \pm 0,27^{*}$ & $17,26 \pm 0,46$ & $18,57 \pm 0,71$ & $17,22 \pm 0,28$ & $17,70 \pm 0,39$ \\
\hline AOA, \% & $84,1 \pm 7,2$ & $61,3 \pm 4,1^{*}$ & $58,5 \pm 5,6^{*}$ & $44,8 \pm 4,9^{*}$ & $72,2 \pm 5,4 \#$ & $65,3 \pm 5,2^{*}$ & $58,7 \pm 4,1^{*}$ \\
\hline
\end{tabular}

Примітки: * - різниця показників вірогідна $(p \leq 0,05)$ порівняно з контрольними тваринами;

\# - різниця показників вірогідна $(p \leq 0,05)$ порівняно $з$ нелікованими тваринами.

Таблиця 3. Вплив нанохрому цитрату на показники оксидантно-антиоксидантного гомеостазу в печінці щурів

\begin{tabular}{|c|c|c|c|c|c|c|c|}
\hline \multirow{3}{*}{ Показники } & \multicolumn{7}{|c|}{ Умови досліду } \\
\hline & \multirow{2}{*}{ Контроль } & \multicolumn{3}{|c|}{ Нанохрому цитрат } & \multicolumn{3}{|c|}{ Нанохрому цитрат + тіотриазолін } \\
\hline & & $3 \mathrm{Mr} / \mathrm{kr}$ & 4,5 мг/кг & $5 \mathrm{Mr} / \mathrm{kг}$ & $3 \mathrm{мг} / \mathrm{kг}$ & 4,5 мг/кг & $5 \mathrm{Mr} / \mathrm{kг}$ \\
\hline MA, & 35 & $41,64 \pm 1,25^{*}$ & $45,37 \pm$ & $51,67 \pm 0,29 *$ & $37,75 \pm 0,74$ & $45,70 \pm 1,84^{*}$ & $45,38 \pm 0,66^{*}, \#$ \\
\hline OMБ, & $17,02 \pm 0,85$ & $25,85 \pm 1,07^{*}$ & $26,94 \pm 0,57^{\star}$ & $26,39 \pm 0,42^{*}$ & $20,73 \pm 0,44 \#$ & $22,74 \pm 0,79 \#$ & $24,13 \pm 1,35$ \\
\hline KT, мкмо & $19,48 \pm 0,59$ & $14,36 \pm 0,07^{*}$ & $15,49 \pm 0,27^{\star}$ & $11,93 \pm 0,36$ * & $17,62 \pm 0,87 \#$ & $15,07 \pm 0,85^{\star}$ & $13,82 \pm 0,53^{*}$ \\
\hline Г-SH, мкмоль/г & $7,42 \pm 0,27$ & $5,62 \pm 0,11^{*}$ & $6,29 \pm 0,18^{*}$ & $4,87 \pm 0,30 *$ & $6,67 \pm 0,33$ & $6,46 \pm 0,13^{*}$ & $6,05 \pm 0,38$ \\
\hline
\end{tabular}

Примітка: * - різниця показників вірогідна $(p \leq 0,05)$ порівняно $з$ контрольними тваринами;

\# - різниця показників вірогідна $(p \leq 0,05)$ порівняно з нелікованими тваринами.

ISSN 2312-0967. Фармацевтичний часопис. 2017. № 1 
Фармакологічні дослідження біологічно активних речовин Pharmacological researches of biologically active substances

дантну рівновагу, а й відомій його гепато- та нефропротекторній дії - органів, що беруть участь в детоксикації та елімінації сполуки [1, 5, 6, 15]. Не виключена протиотрутна дія тіотриазоліну також завдяки комплексоутворенню, зменшиню абсорбції та прискореному виведенню токсиканта з організму, що потребує подальших досліджень.

Висновки. 1. У гострому досліді на щурах на тлі токсичних доз нанохрому цитрату $\left(\mathrm{DL}_{0}, \mathrm{DL}_{50}, \mathrm{DL}_{100}\right)$ тривале (7 діб) лікувально-профрілактичне введення тіотриазоліну (100 мг/кг) зменшує прояви інтоксикації та летальність тварин.
2. Інтоксикація тварин високими дозами нанохрому цитрату супроводжується посиленням в організмі процесів вільнорадикального окиснення ліпідів і окиснювальної модифрікації білків, зниженням активності каталази, загальної антиоксидантної активності плазми крові, вмісту вільних SH-груп і відновленого глутатіону.

3. Одноразове уведення тіотриазоліну запобігає розвитку порушень оксидантно-антиоксидантного гомеостазу в організмі тварин лише на тлі мінімально токсичної дози нанохрому цитрату, а на тлі летальних доз одноразове введення тіотриазоліну малоефективне.

\title{
КОРРЕГИРУЮЩЕЕ ВЛИЯНИЕ ТИОТРИАЗОЛИНА НА ТОКСИЧНОСТЬ И СОСТОЯНИЕ ПРО- И АНТИОКСИДАНТНОГО ГОМЕОСТАЗА У КРЫС НА ФОНЕ ТОКСИЧЕСКОГО ДЕЙСТВИЯ НАНОХРОМА ЦИТРАТА
}

\author{
Е. В. Садогурская, Р. Б. Косуба, И. Н. Яремий \\ ВГУз «Буковинский государственный медицинский университет», Черновцы \\ sadogurska.katya@mail.ru
}

Цель работы. Изучить корректирующее воздействие тиотриазолина на общую токсичность и параметры биохимической детоксикации при действии токсических доз нанохрома цитрата.

Материалы и методы. В остром опыте на крысах исследовано влияние тиотриазолина (100 мг/кг) на токсичность нанохрома цитрата (НХЦ) и состояние про- и антиоксидантного гомеостаза на фроне однократного введения сублетальних $\left(\mathrm{DL}_{0}\right)$ и летальных $\left(\mathrm{DL}_{50}, \mathrm{DL}_{100}\right)$ доз соединения (3 мг/кг, 4,5 мг/кг, 5 мг/кг). В эритроцитах крови определяли содержание малонового альдегида (MA), восстановленного глутатиона (Г-SH) и активность каталазы (КТ). В плазме крови - общую антиоксидантную активность (AOA), содержание окислительно-модисрицированных белков (ОМБ) и свободных SH-групп. В постядерных супернатантах гомогенатов печени определяли содержание MA, Г-SH, OMБ и активность КT.

Результаты и обсуждение. Введение тиотриазолина с лечебной целью на фоне сублетальных и летальных доз НХЦ значительно уменьшило общие проявления отравления, продлило жизнь животных. Если нелеченные животные погибали на 2-3 сутки, то при действии тиотриазолина - на 6-8 сутки. При введении токсических доз НХЦ усиливаются процессы свободнорадикального окисления липидов и белков, снижается активность КТ, АОА плазмы крови, содержание свободных SH-групп и восстановленного Г-SH. Эфрфективнее оказалось действие тиотриазолина на фоне минимально токсической дозы НХЦ (3 мг/кг) - по сравнению с нелеченными животными достоверно возросла AOA в плазме крови без заметных изменений содержания SH-групп.

Выводы. В остром опыте на крысах на фроне токсических доз нанохрома цитрата длительное введение тиотриазолина уменьшает проявления интоксикации и летальность животных. Тиотриазолин предотвращает развитие нарушений оксидантно-антиоксидантного гомеостаза в организме интоксицированных животных, однако на фроне летальных доз нанохрома цитрата однократное введение тиотриазолина малоэффективное.

Ключевые слова: нанохрома цитрат; токсичность; про- и антиоксидантный гомеостаз; тиотриазолин.

\section{CORRECTIVE EFFECT OF THIOTRIAZOLINE ON TOXICITY AND CONDITION OF PRO- AND ANTI- OXIDANT HOMEOSTASIS IN RATS AGAINST TOXIC ACTION OF NANOCHROMIUM CITRATE}

\author{
K. V. Sadogurska, R. B. Kosuba, I. M. Yaremiy \\ Bukovynian State Medical University, Chernivtsi \\ sadogurska.katya@mail.ru
}

The aim of the work. Researching a corrective effect of thiotriazoline on general toxicity and parameters of biochemical detoxication under conditions of action of nanochromium citrate toxic doses.

Materials and Methods. The effect of thiotriazoline (100 mg/kg) on nanochromium citrate (NCC) toxicity and condition of pro- and antioxidant homeostasis against a single injection of sublethal $\left(\mathrm{DL}_{0}\right)$ and lethal $\left(\mathrm{DL}_{50}, \mathrm{DL}_{100}\right)$ doses of the compound

ISSN 2312-0967. Pharmaceutical review. 2017. № 1 
Фармакологічні дослідження біологічно активних речовин Pharmacological researches of biologically active substances

( $3 \mathrm{mg} / \mathrm{kg}, 4,5 \mathrm{mg} / \mathrm{kg}, 5 \mathrm{mg} / \mathrm{kg}$ ) is examined in an acute experiment on laboratory rats. The content of Malone aldehyde (MA), reduced glutathione ( $\Gamma-\mathrm{SH})$ and catalase activity $(\mathrm{CA})$ was detected in the erythrocytes. General antioxidant activity (GAA), the content of oxidizing-modified proteins (OMP) and free SH-groups were detected in the blood plasma. The content of MA, $\Gamma-\mathrm{SH}, \mathrm{OMP}$ and CA was studied in the post-nuclear supernatants of the liver homogenates.

Results and Discussion. Administration of thiotriazoline with therapeutic purpose against sublethal and lethal doses of NCC is found to decrease considerably the signs of intoxication and increase survival of animals. Since untreated animals died on the 2-3 days, under thiotriazoline action it occurred on the 6-8 days. Intoxication of animals with high doses of NCC is accompanied by intensification of the processes of free radical lipid oxidation and protein oxidation modification in the body, reduced activity of catalase, general antioxidant activity of the blood plasma, content of free SH-groups and reduced glutathione. The action of thiotriazoline against minimally toxic dose of NCC (3 mg/kg) appeared to be more effective as compared to untreated animals antioxidant activity in the blood plasma increased reliably without noticeable changes of SH-groups content.

Conclusions. A prolonged administration of thiotriazoline decreased the signs of intoxication and lethal outcome of animals against toxic doses of nanochromium citrate in an acute experiment. Thiotriazoline prevents the development of disorders of oxidizing-antioxidizing homeostasis in the body of intoxicated animals, although, a single injection of thiotriazoline against lethal doses of nanochromium citrate is less effective.

Key words: nanochromium citrate; toxicity; pro- and antioxidant homeostasis; thiotriazoline.

\section{Список літератури}

1. Бибик Е. Ю. Тиотриазолин - потенциальное лекарственное средство с детоксикационной активностью / Е. Ю. Бибик, К. А. Фомина, М. В. Ющак // Український медичний альманах. - 2009. - Т. 12, № 1. - С. 213-217.

2. Веревкина И. В. Колориметрический метод определения HS-групп и S-S-связей в белках при помощи 5,5'-дитиобис(2-нитробензойной) кислоты) / И. В. Веревкина, А. И. Точилкин, Н. А. Попова // Современные методы в биохимии. - М. : Медицина, 1977. - С. 223-231. 3. Доклінічні дослідження лікарських засобів (методичні рекомендації) / за ред. О. В. Стефранова. - К. : Авіцена, 2001. -528 c.

4. Іскра Р. Я. Біохімічні процеси в організмі тварин за дії різних сполук хрому (III): автореф. дис. на здобуття ступеня д-ра біол. наук: 03.00.04 / Р. Я. Іскра, НААН України. - Л., 2013. -44 с.

5. Копчук Т. Г. Фармакологические эффректы тиотриазолина / Т. Г. Копчук // Современный научный вестник. 2014. - № 10 (206). - С. 66-71.

6. Метаболитные и метаболитотропные препараты в системе кардио- и органопротекции / [Чекман И. С., Горчакова Н. А., Французова С. Б. и др.]. - Киев, 2009. - 159 с.

7. Метод определения активности каталазы / М. А. Королюк, М. И. Иванова, И. Г. Майорова [и др.] // Лаб. дело. - 1998. - № 1. - С. 16-18.

8. Механізм енерготропної та антиоксидантної дії тіотриазоліну / І. Ф. Бєленічев, І. А. Мазур, М. А. Волошин [та ін.] // Новости медицины и фрармации. - 2008. - № 13-14. - C. 249-250.

9. Мещишен І. Ф. Метод визначення окисно-модифрікованих білків плазми (сироватки) крові / І. Ф. Мещишен // Буковинський медичний вісник. - 1998. - Т. 2, № 1. - С. 156-158.

10. Микроэлементозы человека / [Авцын А. П., Жаворонков А. А., Раш М. А. и др.]. - М. : Медицина, 1991. - 496 с. 11. Нанонаука, нанобіологія, нанофармація / [Чекман І. С., Ульберг 3. Р., Маланчук В. О. та ін.]. - К. : Поліграфр плюс, 2012. - 328 с.

12. Наночастинки: важливість сьогодні, класифрікація, використання в медицині, токсичність / І. А. Бандас,
І. Я. Криницька, М. І. Куліцька [та ін.] // Медична та клінічна хімія. - 2015. - Т. 17, № 3. - С. 123-128.

13. Пат. 15770 Україна. МПК А61К31/00. Застосування тіотриазоліну як детоксиканту при інтоксикації солями важких металів / Гордієнко В. В., Косуба Р. Б. ; заявл. 20.01.2006; Бюл. № 7.

14. Пат. 29856 Україна. В01J13/00, В82B3/00. Спосіб отримання аквахелатів нанометалів «Ерозійно-вибухова нанотехнологія отримання аквахелатів нанометалів» / Косінов М. В., Каплуненко В. Г.; заявл. 25.10.2007 ; опубл. 25.01.2008 ; Бюл. № 2.

15. Ренальні ефекти тіотриазоліну : методичні рекомендації / О. В. Геруш, Р. Б. Косуба, О. Р. Піняжко [та ін.]. - Київ, 2003. - 20 c.

16. Садогурська К. В. Вивчення гострої токсичності нанохрому цитрату за різних шляхів уведення / К. В. Садогурська // Фармацевтичний часопис. - 2015. - № 4 (36). - C. 56-59.

17. Стальная И. Д. Методы определения малонового диальдегида с помощью тиобарбитуровой кислоты / И. Д. Стальная, Т. Г. Гаришвили // Современные методы в биохимии / Под. ред. В.Н.Ореховича. - М. : Медицина, 1977. - 392 с.

18. Яремій І. М. Вплив настоянки арніки гірської на стан пероксидного окислення ліпідів та захисної глутатіонової системи печінки щурів за умов експериментального токсичного гепатиту / І. М. Яремій, Н. П. Григор'єва, І. Ф. Мещишен // Укр. біохім. журн. - 1998. - Т. 70, вип. 2. - C. 78-82.

19. Cefalu W. T. Role of Chromium in Human Health and in Diabetes / W. T. Cefalu, F. B. Hu // Diabetes Care. - 2004. - Vol. 27, № 14. - P. 2741-2751.

20. Trivalent chromium induces oxidative stress in goldfish brain / O. V. Lushchak, O. I. Kubrak, I. M. Torous [et al.] // Chemosphere. - 2009. - Vol. 75. - P. 56-62.

21. Effects of chromium nanoparticle dosage on growth, body composition, serum hormones and tissue chromium in Sprague-Dawley rats / L. Y. Zha, Z. R. Xu, M. Q. Wang, L. Y. Gu // J. Zhejiang Univ. Sci. B. - 2007. - Vol. 8, № 5. - P. 323-330.

ISSN 2312-0967. Фармацевтичний часопис. 2017. № 1 
Фармакологічні дослідження біологічно активних речовин Pharmacological researches of biologically active substances

\section{References}

1. Bibik EYu, Fomina KA, Yushchak MV. [Thiotriazoline potential drug with detoxification activity]. Ukr med alm. 2009; 1(12): 213-7. Ukrainian.

2. Verevkina IV, Tochilkin AI, Popova NA. Modern methods in biochemistry. [Современные методы в биохимии] Moskva: Meditsina; 1977. Russian.

3. Stefanova OV. Preclinical studies of drugs (guidelines). [Доклінічні дослідження лікарських засобів (методичні рекомендації)] Kyiv: Avicena; 2001. Ukrainian.

4. Iskra RYa. Biokhimichni protsesy $v$ orhanizmi tvaryn za dii riznykh spoluk khromu (III). [Біохімічні процеси в організмі тварин за дії різних сполук хрому (III)] Thesis. Dis. Dr. biol. Sciences: 03.00.04: Lviv; 2013. Ukrainian.

5. Kopchuk TG. [Pharmacological effects Thiotriazoline]. Sovremen nauch Vestnik 2014; 10 (206): 66-1. Ukrainian.

6. Chekman IS, Gorchakova NA, Frantsuzova SB, Mintser VO, SvintsitskiyAS. Metabolite and metabolitotropnye drugs in cardio system and organ protection. [Метаболитные и метаболитотропные препараты в системе кардио- и органопротекции] Kyiv; 2009. Ukrainian.

7. Korolyuk MA, Ivanova LI, Mayorova IG, Tokareva VE. [The method for determining the activity of catalase]. Lab delo. 1998; 1:16-18. Russian.

8. Byelenichev IF, Mazur IA, Voloshyn MA, Gorchakova NO, Chekman IS. [The mechanism of energotropic and antioxidant action of Thiotriazoline]. Nov med i farm 2008; 13-14: 249-50. Ukrainian.

9. Meshhyshen IF. [The method of determining the oxidation-modified plasma proteins (serum) blood]. Buk med visnyk. 1998; 1(2): 156-58.

10. Avtsyn AP, Zhavoronkov AA, Rish MA, Strochkova LS. Microelementoses person. [Микроэлементозы человека] Moskva: Meditsina; 1991. Russian.

11. Chekman IS, Ulber ZR, Malanchuk VO, Gorchakova NO, Zupanecz IA. Nanosciences, Nanobiology, Nanopharmaceutics. [Нанонаука, нанобіологія, нанофармація] Kyiv: Poligraf plyus; 2012. Ukrainian.

12. Bandas IA, Krynyczka IYa, Kuliczka MI, Korda MM.
[Nanoparticles: the importance of today, the classification used in medicine, toxicity]. Med ta klin khimiya. 2015; 3 (17): 123-8. Ukrainian.

13. Gordiyenko VV, Kosuba RB, inventors; Bukovyna State Medical University, assignee. Application Thiotriazoline as detoxicant intoxication with salts of heavy metals. UA 15770 (Patent) 2006 Jan 20. Ukrainian.

14. Kosinov MV, Kaplunenko VG, inventors; Ltd. «Nanomaterials and Nanotechnologies», assignee. Method akvahelativ nanometaliv «Erosion-explosive nanotechnology receiving akvahelativ nanometaliv». UA 29856 (Patent) 2008 Jan 25. Ukrainian.

15. Gerush OV, Kosuba RB, Pinyazhko OR, Gordiyenko VV, Gerush IV. Renal effects of Thiotriazoline: guidelines [Ренальні ефректи тіотриазоліну: методичні рекомендації] Kyiv; 2003. Ukrainian.

16. Sadogurska KV. [The study of acute toxicity nanochrom citrate under different routes of administration]. Farmacevt chasop. 2015; 4 (36): 56-9. Ukrainian.

17. Stal'naya ID, Garishvili TG. Methods of determining malonic dialdehyde using thiobarbituric acid [Методы определения малонового диальдегида с помощью тиобарбитуровой кислоты] Moskva: Meditsina; 1977. Russian.

18. Yaremij IM, Grygoryeva NP, Meshhyshen IF. [The influence of mountain arnica tincture on the state of lipid peroxidation and protective systems hlutationovoyi liver of rats under the experimental toxic hepatitis]. Ukr bioxim zhurn. 1998; 70: 78-2. Ukrainian.

19. Cefalu WT. [Role of Chromium in Human Health and in Diabetes] Diabetes Care. 2004; 14 (27): 2741-51.

20. Lushchak OV, Kubrak OI, Torous IM, Nazarchuk TV, Storey $\mathrm{KB}$, Lushchak VI. [Trivalent chromium induces oxidative stress in goldfish brain] Chemosphere. 2009; 75: 56-2.

21. Zha LY, Xu ZR, Wang MQ, Gu LY. [Effects of chromium nanoparticle dosage on growth, body composition, serum hormones and tissue chromium in Sprague-Dawley rats] J Zhejiang Univ Sci B. 2007; 5 (8): 323-30. 